Article

\title{
Quality Assessment of Raw Honey Issued from Eastern Romania
}

\author{
Aida Albu, Cristina-Gabriela Radu-Rusu *, Ioan Mircea Pop *, Gabriela Frunza and Gherasim Nacu
}

check for updates

Citation: Albu, A.; Radu-Rusu, C.-G.; Pop, I.M.; Frunza, G.; Nacu, G.

Quality Assessment of Raw Honey Issued from Eastern Romania.

Agriculture 2021, 11, 247. https:// doi.org/10.3390/agriculture11030247

Academic Editors: Gianluca Caruso, László Baranyai and Vasile Stoleru

Received: 31 January 2021

Accepted: 3 March 2021

Published: 14 March 2021

Publisher's Note: MDPI stays neutral with regard to jurisdictional claims in published maps and institutional affiliations.

Copyright: (c) 2021 by the authors. Licensee MDPI, Basel, Switzerland. This article is an open access article distributed under the terms and conditions of the Creative Commons Attribution (CC BY) license (https:/ / creativecommons.org/licenses/by/ $4.0 /)$.
Animal Science Faculty, "Ion Ionescu de la Brad" University of Agricultural Sciences and Veterinary Medicine, 8 Mihail Sadoveanu Alley, 700489 Iasi, Romania; albu.aida@uaiasi.ro (A.A.); frunza.gabriela@uaiasi.ro (G.F.); gnacu@uaiasi.ro (G.N.)

* Correspondence: cradurusu@uaiasi.ro (C.-G.R.-R.); popim@uaiasi.ro (I.M.P.)

\begin{abstract}
Romania is known among the main European honey producers, due to the variety of landforms as well as the diversity of the flora. Thirty-four honey samples of the acacia, linden and multifloral types, produced in eastern Romania and collected during 2013-2018, were physicochemically analyzed using methods provided by the national and EU standards. The results of water-insoluble solids, color and refractive index were found to be $0.023-0.131 \%, 0.3-76.4 \mathrm{~mm}$ Pfund and 1.485-1.499, respectively. The moisture content ranged between $15.20 \%$ and $20.77 \%$, solid substances content ranged between $79.23 \%$ and $84.80 \%$ and total soluble substances content ranged between $77.83^{\circ}$ Brix and $83.26^{\circ}$ Brix. The obtained values of specific gravity were from 1.414 to $1.450 \mathrm{~g} / \mathrm{cm}^{3}$, pH ranged from 3.673 to 5.503 and free acidity ranged between 2.4 meq and $50 \mathrm{meq} \mathrm{kg}^{-1}$. The ash content and the electrical conductivity varied between 0.030 and $0.543 \%$ and 130 and $679 \mu \mathrm{S} \mathrm{cm}^{-1}$, respectively. Pearson's correlation analysis showed an intense association of the ash content with electrical conductivity $(r=0.81)$. Our findings reveal the qualitative level of Romanian honey and the variation in quality parameters due to factors such as geographical region, climatic conditions, botanical origin and handling or storage conditions.
\end{abstract}

Keywords: raw honey; conductivity; specific gravity; total soluble substances; refractive index; quality

\section{Introduction}

Honey is known and recognized as a wholesome food consumed due to its extraordinary composition, in terms of nutritional and therapeutic features [1,2]. Honey was considered to have healing properties by the ancient civilizations going back in time from the Chinese Empire to the Egyptian Empire. Nowadays, it is quite a trend to investigate alternative natural foods and molecules, such as bee products, which have been supposed to trigger active pharmacologic and metabolic pathways and to generate beneficial effects on consumers' health. [3].

Romania has an ancient tradition of beekeeping and now is one of the most important honey producers in Europe, due to the variety of landforms as well as the diverse and very rich flora. In the Romanian flora, there is a series of species of honey plants that stand out through a high honey production. This country has potential to offer sufficient and variate botanical resources to the indigenous bees (Apis mellifera carpatica) in order to obtain a wide panel of unifloral and multifloral honeys, such as the linden (Tilia tomentosa) type, the acacia sort (Robinia pseudoacacia), the sunflower variety (Helianthus anuus) and, of course, the multifloral type (usually from spring-summer meadows and grasslands). North East Romania, specifically the historical province of Moldova, is known as the largest linden massive [4-6]. From the mountains to the plains, the eastern region of Romania is rich in cultivated and spontaneous polliniferous and nectariferous plants. 
This food contains many important constituents such as sugars, acids, proteins, vitamins, enzymes and micro- and macro-elements [7]. The low water inner content is among the most important traits with relevance in maintaining honey freshness, stopping the development of yeasts and avoiding fermentative processes. Yeast and mold proliferation in honey could be regulated by the free acidity and water content within [8]. Both electrical conductivity and crude ash analyses are frequently used in honey quality inspections. Those traits, especially electrical conductivity, are considered very good criteria for assessment of the botanical origin and purity of honey [9]. Legislation has established maximum allowed values for some parameters, such as a maximum $20 \%$ moisture content, maximum 50 meq kg ${ }^{-1}$ free acidity, maximum acceptable content of water-insoluble solids no more than $0.1 \%$ and no more than $0.5 \%$ for pressed honey and a maximum permitted value of $0.8 \mu \mathrm{S} \mathrm{cm}^{-1}$ conductivity for nectar honey, with the exception of chestnut honey which should be not less than $0.8 \mu \mathrm{S} \mathrm{cm}^{-1}[10,11]$. Such physical and chemical traits are keystones on the way to assess honey quality and to identify its authenticity and origin. All honey parameters are correlated twice. Many studies have shown that the variation in one parameter leads to the modification of the other parameters such as ash and electrical conductivity and refractive index with specific gravity and total soluble substances.

In this work, studies were carried out to show the high quality of Romanian honey, quality that remains high regardless of the geographical area and year of harvest.

\section{Materials and Methods}

Thirty-four raw honey samples produced by Apis mellifera of three of the most known honey types: acacia (A) (twelve samples), linden (L) (ten samples) and multifloral (M) (twelve samples), were collected during 2013-2018 directly from beekeepers. The honey produced in eastern Romania comes from different sites of Iasi, Vaslui and Suceava counties (Figure 1a,b). The collection of honey samples was carried on throughout different years, from 2013 to 2018, during the period of maximum flowering of melliferous plants (acacia and linden). Raw honey samples were kept in glass jars, preserved at room temperature $\left(20 \pm 3{ }^{\circ} \mathrm{C}\right)$, away from light. The analyses were performed within a maximum of 2 weeks from the arrival of the samples to avoid their degradation as well as the modification of their parameters, taking into account the fact that they were raw honey samples and not commercial honey. The analyses were performed in triplicate. The crystallized raw honey samples were liquefied at $40{ }^{\circ} \mathrm{C}$ in a water bath (manufacturer: Memmert GMBH - Schwabach, Germany). Homogenized samples were filtered through a double-layered gauze to retain the biggest impurities prior to the analysis.

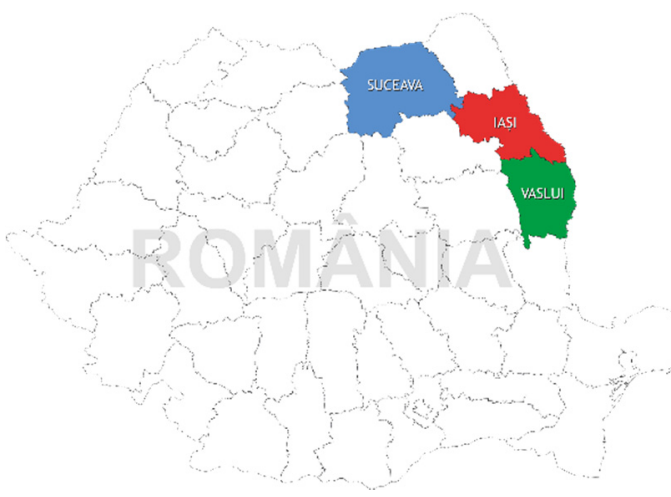

(a)

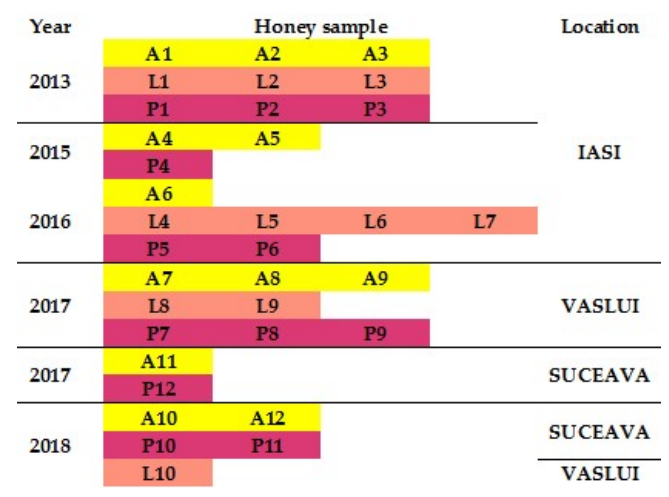

(b)

Figure 1. (a) Locations of honey production; (b) year, type and location of studied honey samples. 


\subsection{Water-Insoluble Solids}

The gravimetric method was applied to assess the water-insoluble solids (WIS). Ten grams of the homogenized honey sample was weighed on the PI-214 DENVER analytical scales (manufacturer: Denver Instrument GMBH - Gottingen, Germany). Prior to filtering through a qualitative-type filter paper adjusted prior to constant mass, the sample was diluted with distilled water. The sample was dissolved in distilled water and filtered through qualitative filter paper adjusted prior to constant mass. After several washes, the filter paper with the water-insoluble solids was dried in an ESAC 100 oven (manufacturer: S.C. Electronic April Aparatură Electronică Specială S.R.L. - Cluj-Napoca, Romania) at $105{ }^{\circ} \mathrm{C}$ till reaching constant mass, and then it was weighed on the analytical balance. The content of water-insoluble solids was calculated by the difference between the filter paper with water-insoluble solids weight and filter paper weight and was expressed as a percentage $[10,12]$

\subsection{Color}

Honey pigmentation was spectrophotometrically analyzed at $635 \mathrm{~nm}$ wavelength, using the Shimadzu UV-1700 Pharma Spec instrument (manufacturer: Shimadzu Corporation, Analytical Instruments Division, Kyoto, Japan) from $50 \%(w / v)$ honey aqueous solutions after honey samples were centrifuged at $3200 \mathrm{rpm}$ for $5 \mathrm{~min}$ [13-15] in the UNIVERSAL 320 centrifuge (manufacturer: Hettich GMBH -Tuttlingen, Germany). The absorbance units were converted in mm Pfund using the relation

$$
\text { Pfund }(\mathrm{mm})=-38.7+371.39 \times \text { Abs }
$$

in which Pfund = honey color on the Pfund scale ( $\mathrm{mm})$; Abs = the value of the absorbance read at the wavelength of $635 \mathrm{~nm}$.

\subsection{Refractive Index, Moisture and Solid Substances}

Raw honey refractive index measurements were carried on the ABBÉ AR 2008 refractometer (manufacturer: Kruss Scientific GMBH, Hamburg, Germany) (distilled water procedure was used to calibrate the device). The temperature of samples was determined using an EKT Hei-Con temperature sensor (manufacturer: Heidolph GMBH, Schwabach, Germany) and the refractive index, read on a refractometer, was corrected by adding 0.00023 for every $1{ }^{\circ} \mathrm{C}$ above $20^{\circ} \mathrm{C}$. Moisture content was then identified in the table of correspondence between water content and refractive index values at $20^{\circ} \mathrm{C}[10,12,16]$. Moisture content was expressed as a percentage. Solid substances, expressed as \%, were calculated with the formula

$$
\text { SS }(\%)=100-\mathrm{M}
$$

where SS = solid substances (\%); M = moisture sample (\%).

\subsection{Total Soluble Solids}

The total soluble solids were represented by total soluble sugars. The amount of total soluble solids, expressed as Brix degrees (a percentage of sugar is considered to be, at $20^{\circ} \mathrm{C}$, one ${ }^{\circ} \mathrm{Brix}$ ) was read from the table of correspondence between the refractive index at $20^{\circ} \mathrm{C}$ and degrees Brix [17].

\subsection{Specific Gravity}

The gravimetric method was applied to assess the raw honey specific gravity, using the pycnometer device. Values were obtained by dividing the pycnometer mass (bottle of $50 \mathrm{~mL}$ ) filled with honey by the mass of the same bottle, filled with distilled water $[18,19]$. 


\section{6. $p H$ and Free Acidity}

Honey solution $10 \%(w / v)$ was measured on a MULTI 3320 multiparameter (manufacturer: WTW GMBH, Weilheim, Germany) to achieve $\mathrm{pH}$ values $[12,19]$, while free acidity was assessed by using the titration method on the same solution, with $0.1 \mathrm{~N} \mathrm{NaOH}$ (purity 99.6\%, purchased from Lachner-Czech Republic), and the values were expressed in meq $\mathrm{kg}^{-1}[20]$.

\subsection{Ash}

Assessment of ash content in honey samples was carried out by the calcination method $\left(550^{\circ} \mathrm{C}\right)$ in the Nabertherm B180 furnace (manufacturer: Nabertherm GMBH, Lilienthal, Germany); the results were expressed in $\mathrm{g} / 100 \mathrm{~g}[10,20,21]$.

\subsection{Electrical Conductivity}

Electrical conductivity values were obtained by measuring $20 \%$ honey solution, calculated on dry matter, with the MULTI 3320 multiparameter (manufacturer: WTW GMBH, Weilheim, Germany). The solution was made with ultrapure water produced by the Barnstead EASY PURE II system (manufacturer: Thermo Fisher Scientific co. 1td., Iowa, USA); the results were expressed in $\mu \mathrm{S} \mathrm{cm} \mathrm{cm}^{-1}[12,19,20]$.

\subsection{Statistical Analyses}

All analyses were carried out in triplicate, firstly, to achieve the main descriptive statistics (mean \pm st. dev., variation coefficient), followed by one-way ANOVA $(p<0.05)$. Pearson's correlation testing was run ( $\mathrm{r}$ ) to highlight causalities between studied parameters of honey samples. IBM SPSS Statistics14.0 version was used for principal component analysis (PCA) to visually observe Pearson's correlation [22]. For hierarchical cluster analysis (HCA), centroid linkage was used to discriminate the honey samples taking into account the values of the parameters determined in this study.

\section{Results}

\subsection{Water-Insoluble Solids}

Water-insoluble solids content ranged within 0.023 and $0.131 \%$ in all mixed samples and varied from $0.023 \%$ to $0.122 \%$ in acacia honey, from $0.032 \%$ to $0.109 \%$ in linden honey and from $0.036 \%$ to $0.131 \%$ in multifloral honey (Table 1 ). The highest average of waterinsoluble solids content was $0.080 \%$, in multifloral honey samples. There are significant differences of this parameter between samples of the same type of honey and between the three types of honey (Figure 2). Statistically significant differences were observed between the means of water-insoluble solids content of acacia and multifloral honeys $(p=0.05)$.

Table 1. Descriptive statistics of studied honey sample parameters $(n=34)$.

\begin{tabular}{|c|c|c|c|c|c|c|c|c|c|}
\hline \multirow{3}{*}{ Parameters } & \multicolumn{3}{|c|}{ Acacia } & \multicolumn{3}{|c|}{ Linden } & \multicolumn{3}{|c|}{ Multifloral } \\
\hline & \multicolumn{9}{|c|}{ Descriptive Statistics } \\
\hline & Min-Max & Mean \pm SD & $\mathrm{CV} \%$ & Min-Max & Mean \pm SD & $\mathrm{CV} \%$ & Min-Max & Mean \pm SD & CV\% \\
\hline WIS (\%) & $0.023-0.122$ & $0.062 \pm 0.03$ & 48.86 & $0.032-0.109$ & $0.070 \pm 0.03$ & 35.84 & $0.036-0.131$ & $0.080 \pm 0.03$ & 41.39 \\
\hline Pfund value (mm) & $0.3-8.8$ & $2.2 \pm 2.66$ & 123.8 & $22.6-76.4$ & $40.2 \pm 15.17$ & 37.77 & $15.4-70.1$ & $44.8 \pm 17.45$ & 38.95 \\
\hline Color intensity & \multicolumn{3}{|c|}{ water white-extra white } & \multicolumn{3}{|c|}{ white-light amber } & \multicolumn{3}{|c|}{ extra white-light amber } \\
\hline RI & $1.485-1.496$ & $1.491 \pm 0.00$ & 0.26 & $1.488-1.499$ & $1.493 \pm 0.00$ & 0.2 & $1.485-1.497$ & $1.492 \pm 0.00$ & 0.25 \\
\hline $\mathrm{M}(\%)$ & $16.20-20.52$ & $18.11 \pm 1.47$ & 8.13 & $15.20-19.32$ & $17.42 \pm 1.14$ & 6.52 & $15.83-20.77$ & $17.93 \pm 1.44$ & 8.03 \\
\hline SS (\%) & $79.48-83.80$ & $81.89 \pm 1.47$ & 1.8 & $80.68-84.80$ & $82.58 \pm 1.14$ & 1.38 & $79.23-84.17$ & $82.07 \pm 1.44$ & 1.75 \\
\hline TSS $\left({ }^{\circ}\right.$ Brix $)$ & $78.08-82.27$ & $80.40 \pm 1.43$ & 1.78 & $79.20-83.26$ & $81.07 \pm 1.11$ & 1.37 & $77.83-82.67$ & $80.60 \pm 1.41$ & 1.75 \\
\hline $\mathrm{SG}\left(\mathrm{g} / \mathrm{cm}^{3}\right)$ & $1.414-1.443$ & $1.430 \pm 0.01$ & 0.68 & $1.422-1.450$ & $1.435 \pm 0.01$ & 0.54 & $1.414-1.446$ & $1.431 \pm 0.01$ & 0.66 \\
\hline $\mathrm{pH}$ & $3.673-5.503$ & $4.272 \pm 0.45$ & 10.57 & $3.742-5.398$ & $4.479 \pm 0.42$ & 9.48 & $3.761-4.468$ & $4.117 \pm 0.21$ & 5.13 \\
\hline $\mathrm{FA}\left(\mathrm{meq} \mathrm{kg} \mathrm{kg}^{-1}\right)$ & $2.4-17.0$ & $8.6 \pm 5.14$ & 59.74 & $12.7-49.8$ & $24.7 \pm 11.88$ & 48.05 & $15.6-50.0$ & $27.1 \pm 11.34$ & 41.85 \\
\hline Ash $(\%)$ & $0.030-0.242$ & $0.088 \pm 0.07$ & 74.94 & $0.080-0.543$ & $0.225 \pm 0.13$ & 59.43 & $0.088-0.277$ & $0.178 \pm 0.06$ & 32.69 \\
\hline $\mathrm{EC}\left(\mu \mathrm{S} \mathrm{cm}^{-1}\right)$ & $130-500$ & $223 \pm 12.31$ & 50.4 & $279-646$ & $506 \pm 120.97$ & 23.92 & $210-679$ & $414 \pm 162.27$ & 39.16 \\
\hline
\end{tabular}

WIS-water-insoluble matter. RI-refractive index. M-moisture. SS—solid substances. TSS—total soluble substances. SG—specific gravity. FA-free acidity. EC-electrical conductivity. 


\subsection{Color}

Honey pigmentation was variable, ranging from white to a light tint of amber. The lowest Pfund value was $0.3 \mathrm{~mm}$ Pfund in acacia honey (A7 sample) and the highest Pfund value was $76.4 \mathrm{~mm}$ Pfund in linden honey, sample L10. In Figure 3, it is observed that the linden and multifloral honey samples have different color shades, for $p<0.05$. Statistically, there was a significant difference in $\mathrm{mm}$ Pfund means between the two types of honey: acacia and linden, and acacia and multifloral.

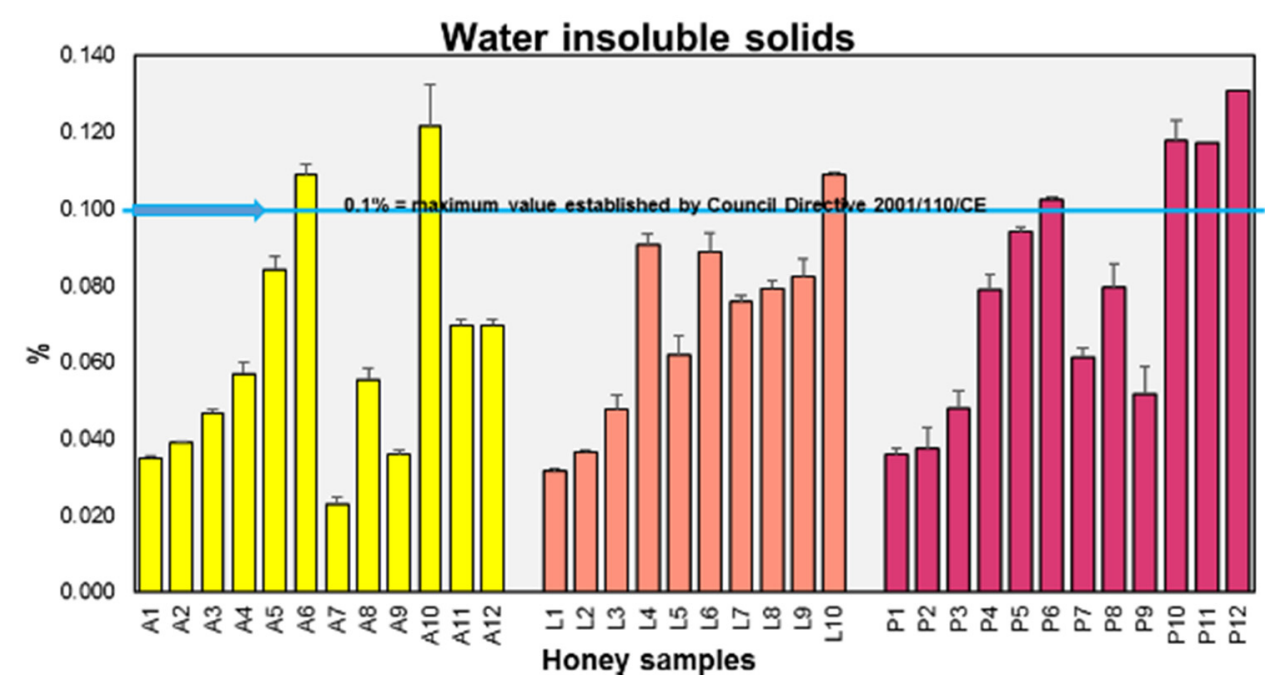

Figure 2. Average values of water-insoluble solids content of honey samples.

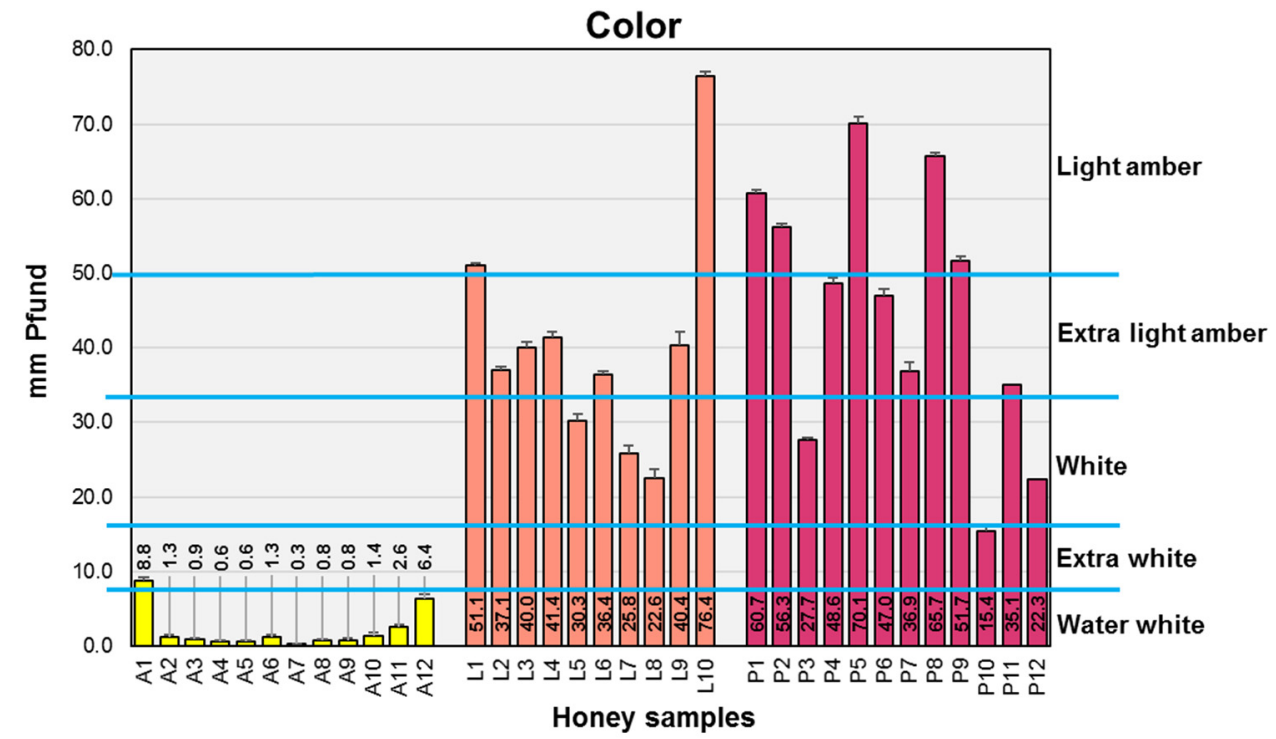

Figure 3. Average values of color intensity of honey samples.

\subsection{Refractive Index and Moisture}

The minimum refractive index value of 1.485 was registered in one sample of acacia honey (A6 sample) and in one multifloral honey (P10 sample), while the maximum value of 1.499 was registered in a linden honey sample (L7 sample) (Table 1). There were no significant differences in average refractive index values between the analyzed honey types. 
The moisture of investigated samples varied between 15.20 and $20.77 \%$ (Table 1 ). The highest average moisture values were measured in acacia and multifloral samples, i.e., 20.40\% in A11, 20.52\% in A12 and 20.77\% in P10 (Figure 4). Acacia and linden honey groups differed significantly $(p<0.05)$, while the significance threshold was not exceeded for the paired comparisons of acacia and multifloral groups, and linden and multifloral groups.

\subsection{Solid Substances and Total Soluble Substances}

The solid substances values ranged between $79.23 \%$ and $84.80 \%$. The highest and lowest average values were in linden honey samples, and values of $82.58 \%$ and of $81.89 \%$ were found in acacia honey samples (Table 1). Acacia and linden groups differed significantly $(p<0.05)$ in terms of solid substances.

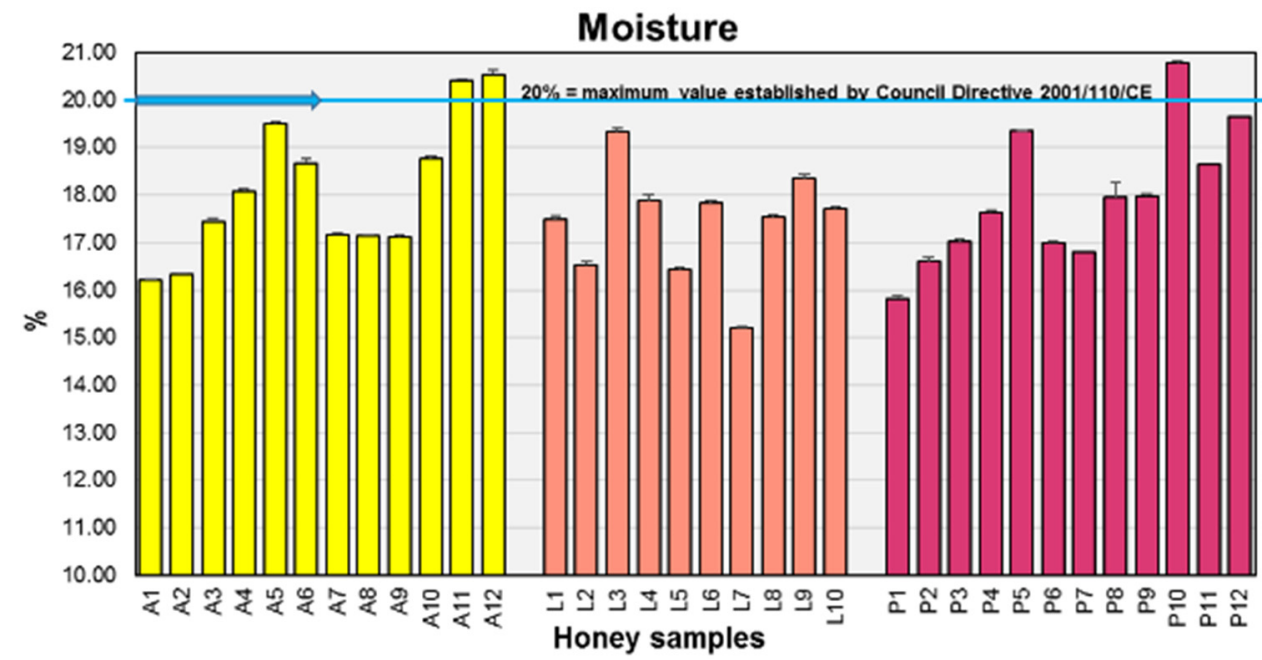

Figure 4. Average values of moisture content of honey samples.

Linden samples revealed the highest content of total soluble substances while the lowest one measured was found in the acacia honey group ( $\left.80.40^{\circ} \mathrm{Brix}\right)$. The maximum value of total soluble substances was $83.26^{\circ}$ Brix in one linden sample, L7, and the minimum value of total soluble substances was $77.83^{\circ}$ Brix in one linden sample, P10. A statistically significant difference $(p<0.05)$ for total soluble substances was found between average values of acacia and linden groups.

\subsection{Specific Gravity}

The average values of specific gravity were measured between 1.414 and $1.450 \mathrm{~g} / \mathrm{cm}^{3}$ (Table 1) and acacia and linden groups differed significantly $(p<0.05)$.

\section{6. $\mathrm{pH}$ and Free Acidity}

$\mathrm{pH}$ values ranged between 3.675 in acacia honey samples and 5.398 in linden honey samples (Table 1).

The lowest free acidity was measured in acacia samples $\left(8.6 \mathrm{meq} \mathrm{kg}^{-1}\right)$, while the highest one, $27.1 \mathrm{meq} \mathrm{kg}^{-1}$, was measured in multifloral honey samples. Figure 5 shows that there are differences between free acidity in honey samples in the same type of honey and between different types of honey. A statistically significant difference $(p<0.05)$ was found between acacia versus linden and multifloral samples. 


\subsection{Ash and Electrical Conductivity}

An average value of $0.088 \%$ ash was obtained in acacia honey samples and of $0.225 \%$ in linden honey samples (Table 1). Electrical conductivity had the lowest average of $223 \mu \mathrm{S} \mathrm{cm}-1$ in acacia samples, then increased in multifloral ones to $414 \mu \mathrm{S} \mathrm{cm}^{-1}$, to reach, eventually, $506 \mu \mathrm{S} \mathrm{cm}^{-1}$ in linden samples. Figure 6 shows that there are differences $(p<0.05)$ between ash and electrical conductivity in honey samples in the same type of honey and between different types of honey.

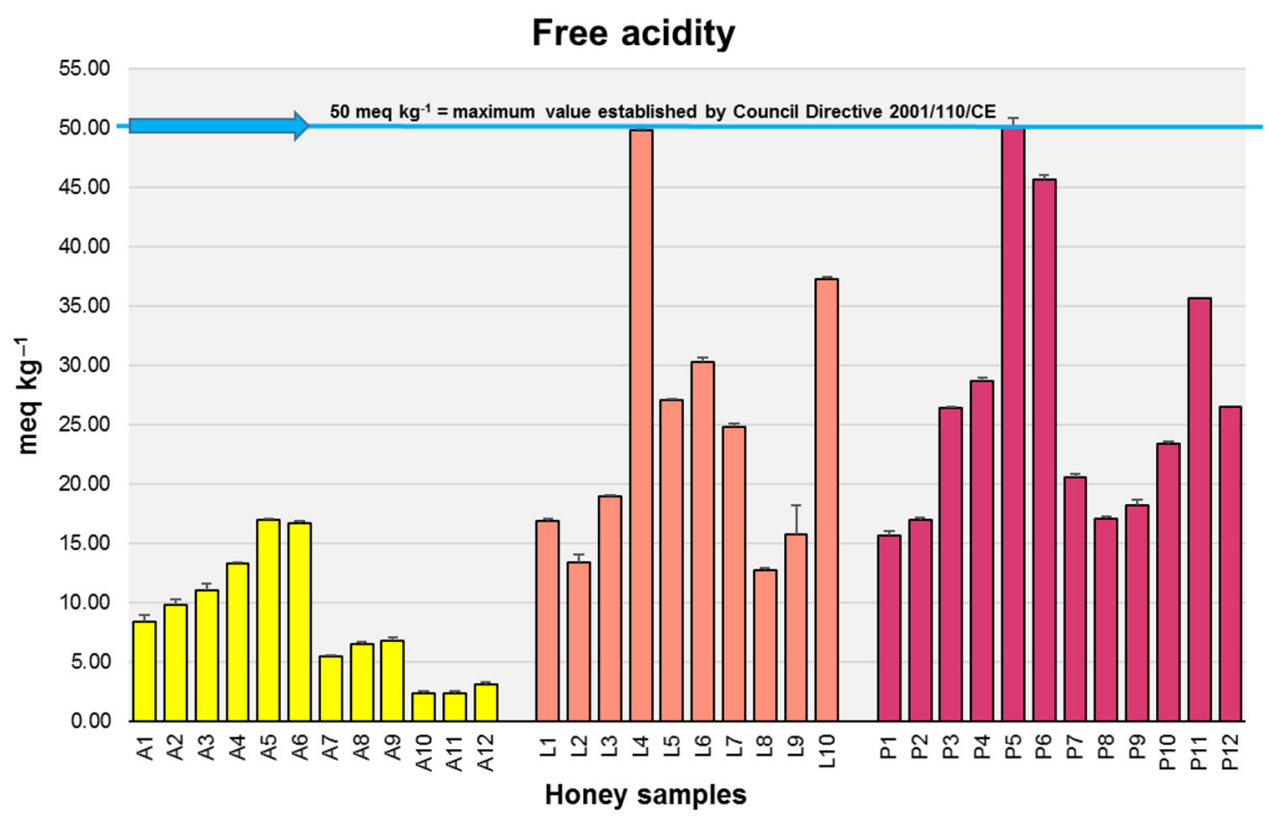

Figure 5. Free acidity values in acacia, linden and multifloral samples.

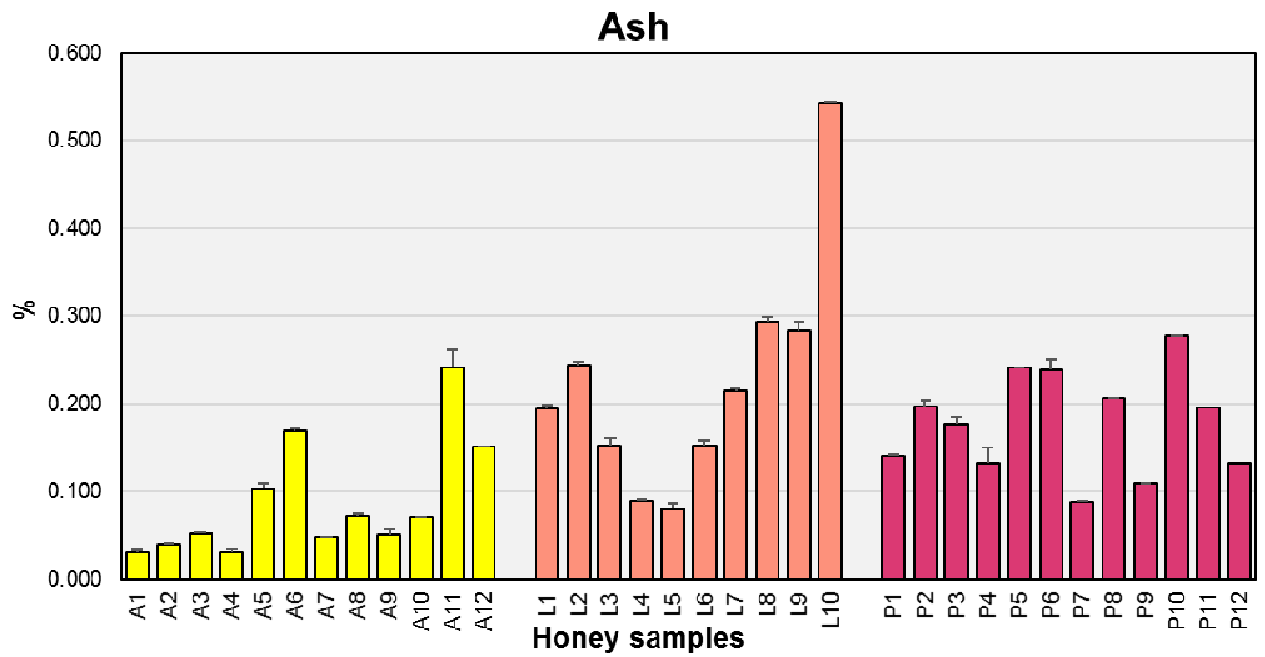

(a)

Figure 6. Cont. 


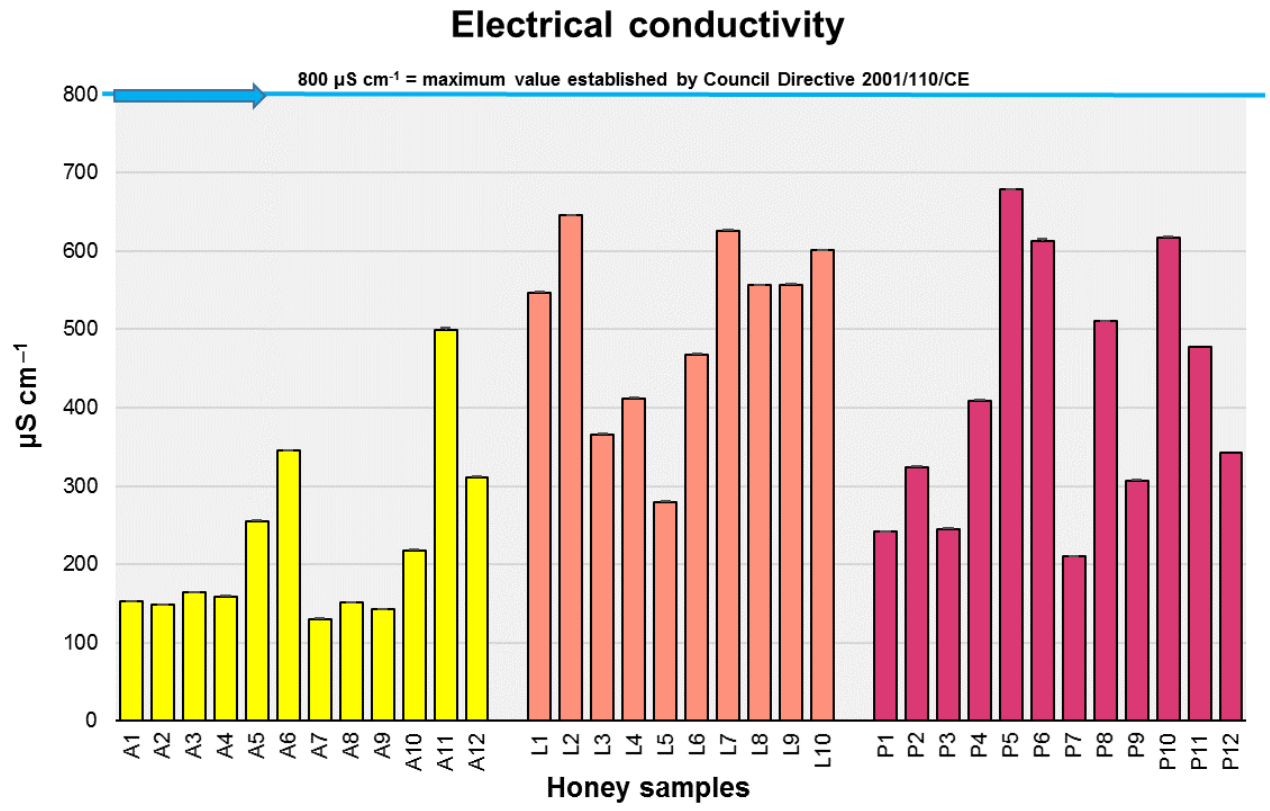

(b)

Figure 6. (a) Average values of ash content of honey samples; (b) average values of electrical conductivity of honey samples.

\subsection{Statistical Analyses}

Figure 7 depicts the identified correlations between the main physical and chemical investigated parameters.

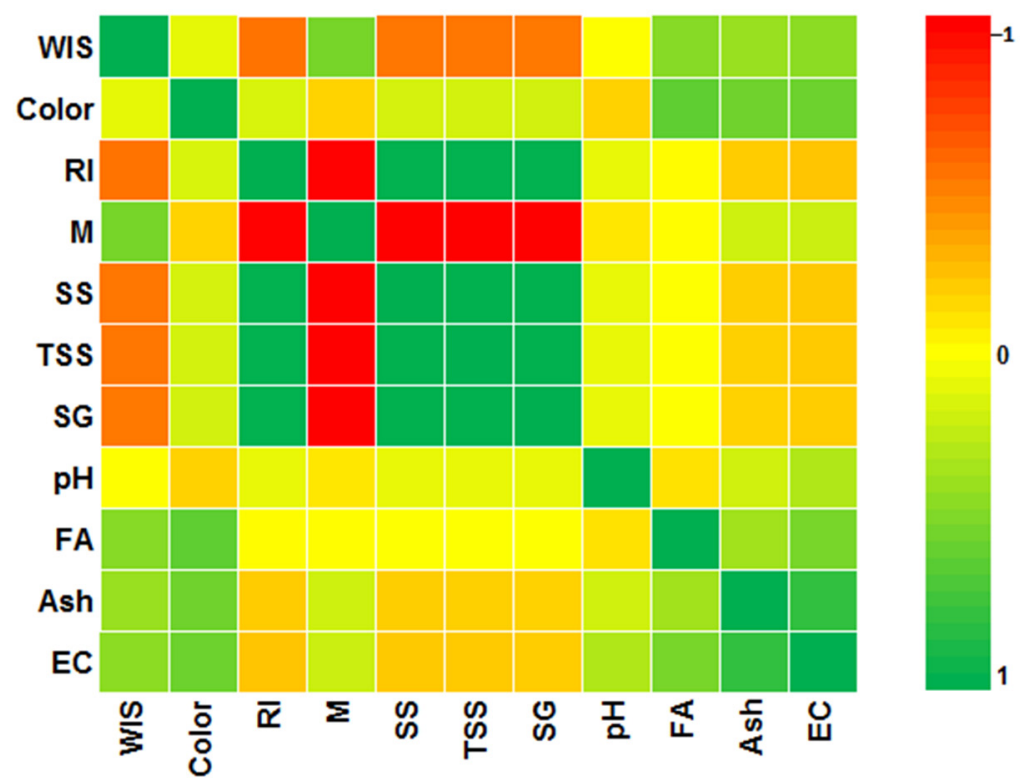

Figure 7. Head map of Pearson's correlation between investigated honey parameters. 
A positive strong correlation between ash and electrical conductivity $(r=0.81)$ was found; refractive index was strongly positively correlated with three parameters: specific gravity $(r=0.99)$, total soluble substances $(r=1)$, solid substances $(r=1)$; solid substances had a strong positive correlation with two parameters: total soluble substances $(r=1)$ and specific gravity $(r=1)$, while total soluble substances had a strong positive correlation with specific gravity $(\mathrm{r}=1)$.

In Figure 8, correlations between the studied parameters can be viewed. Two groups of correlated parameters can be observed: the first group with strong correlations contains refractive index, solid substances, total soluble substances and specific gravity, and the second group contains four parameters: color (mm Pfund), electrical conductivity, ash and free acidity.

\section{Component Plot in Rotated Space}

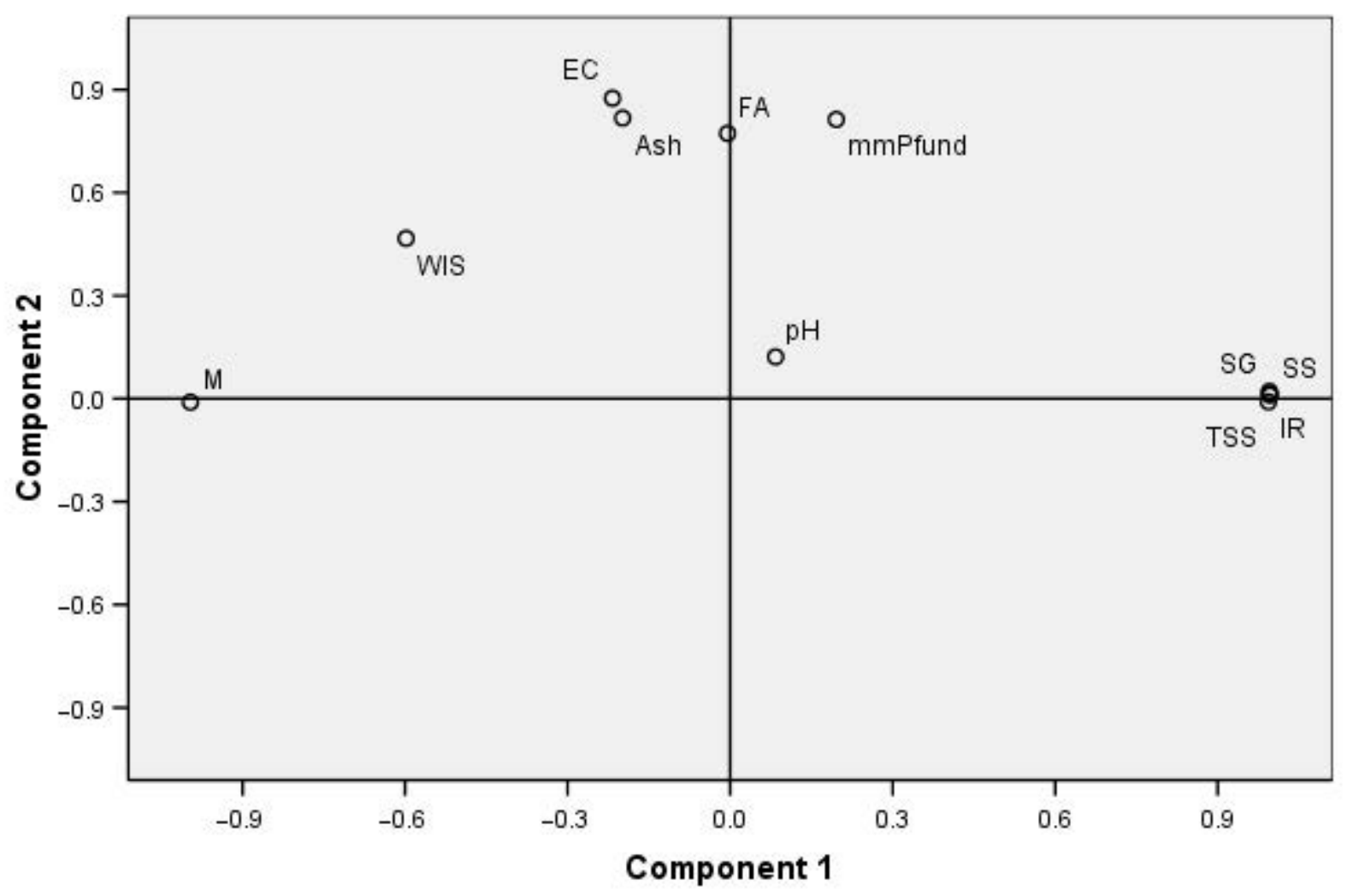

Figure 8. Principal component analysis (PCA) score plot for the analyzed honey samples.

The dendrogram (Figure 9) reveals the formation of four clusters in which we found honey samples with similar characteristics. 


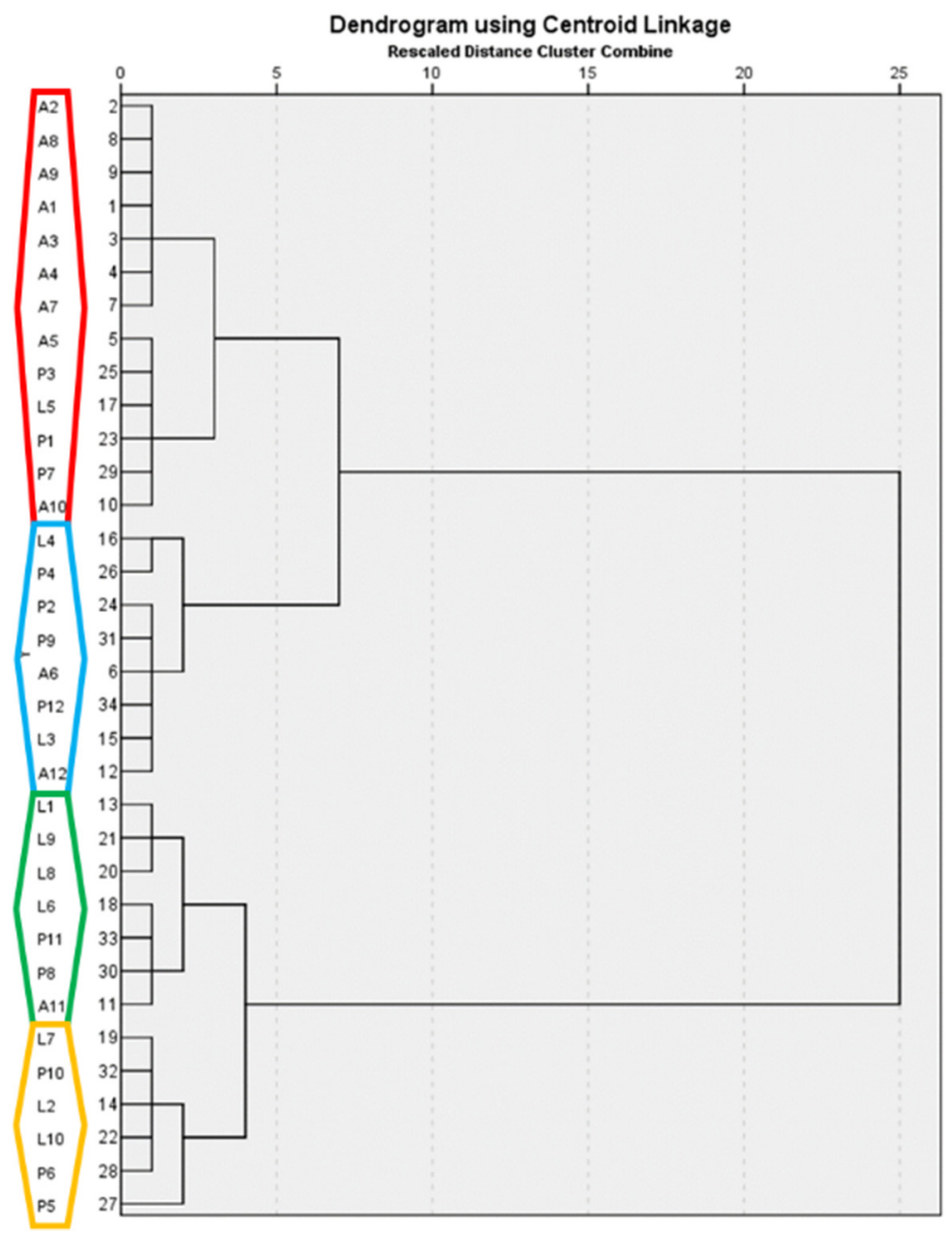

Figure 9. Hierarchical cluster analysis (HCA) of samples based on honey parameters.

\section{Discussion}

Each analyzed parameter is important and contributes to the appreciation of honey quality.

To produce commercially available honey, beekeepers carry out some operations such as extraction by pressing and centrifugation, filtration or storage [22]. The water-insoluble solids remaining in honey after those processes come from organic or inorganic sources such as wax fragments, small pieces of bees' bodies, bee larvae, plant particles such as wood, propolis, pollen, earth and dust [20,23]. Visually, for consumers, the clarity of honey is a quality criterion, so the amount of water-insoluble solids which give clarity to honey must be lower.

In accordance with the legislation for honey quality, the maximum acceptable content of water-insoluble solids in commercial honey is $0.1 \%$ and is tolerated up to $0.5 \%$ for raw honey $[10,11]$. Water-insoluble solids content in $20.59 \%$ of the total analyzed samples exceeded the $0.1 \%$ legal threshold (Figure 2). In $47.06 \%$ of the total honey samples, it reached values between $0.05 \%$ and $0.1 \%$, while $32.35 \%$ of honey samples had less than $0.005 \%$ water-insoluble solids content. Such values suggest that some beekeepers run more careful filtration operations.

Studies made on Libyan honey, honey from the Czech Republic market and on honey collected from the western part of Turkey showed a content of water-insoluble solids under $0.1 \%[22,24-26]$. High values of this parameter were found in honey samples from Brazil of $0.27-0.95 \%$ [27].

The filtering operation run to achieve a clear honey can lead to the loss of a quantity of pollen, a natural constituent of honey, with nutritional characteristics that increase the nutritional and therapeutic properties of honey [28,29]. Considering that the honey samples studied are not for sale as processed commercial products, this parameter indicates a good product quality. 
The qualitative parameters of honey, as it is known, are influenced by many factors; therefore, this product is intensively studied in each country. Various published studies (Table 2) have shown differences in quality between samples of honey from different countries and even from different geographical areas of the same country.

Table 2. Physico-chemical properties of linden, acacia and multifloral honey in the present study and in several previous studies.

\begin{tabular}{|c|c|c|c|c|c|c|c|c|}
\hline References & Country & $\begin{array}{c}M \\
(\%)\end{array}$ & $\begin{array}{c}\text { TSS } \\
\left(\text { Brix }^{\circ}\right)\end{array}$ & $\begin{array}{c}\mathrm{SG} \\
\left(\mathrm{g} \mathrm{cm}^{-1}\right)\end{array}$ & $\mathrm{pH}$ & $\begin{array}{c}\text { FA } \\
\left(\mathrm{meq} \mathrm{kg}^{-1}\right)\end{array}$ & $\begin{array}{c}\mathrm{EC} \\
\left(\mathrm{mS} \mathrm{cm}^{-1}\right)\end{array}$ & Ash (\%) \\
\hline \multicolumn{9}{|c|}{ Linden } \\
\hline Present study & Romania & $15.20-19.32$ & $79.20-83.26$ & $1.422-1.450$ & $3.742-5.398$ & $12.70-49.80$ & $0.279-0.646$ & $0.080-0.543$ \\
\hline $\begin{array}{l}\text { Mărghitaș et al. } \\
(2009)\end{array}$ & Romania & $16.70-19.10$ & - & - & - & - & - & $0.190-0.300$ \\
\hline Stihi et al. (2016) & Romania & $17.20-18.80$ & - & - & $3.840-4.350$ & - & $0.202-0.346$ & - \\
\hline Popescu et al. (2015) & Romania & $5.40-6.00$ & $78.70-82.30$ & - & $3.600-4.700$ & - & $0.410-0.730$ & - \\
\hline Purcarea et al. (2016) & Romania & 18.44 & - & - & 4.425 & - & 0.486 & 0.186 \\
\hline Scripcă et al. (2019) & Romania & $16.00-17.90$ & - & - & - & - & $0.550-0.720$ & - \\
\hline $\begin{array}{l}\text { Kędzierska-Matysek } \\
\text { et al. (2018) }\end{array}$ & Poland & 19.40 & 79.20 & - & 4.130 & 14.50 & 0.579 & - \\
\hline Tomczyk et al. (2019) & Poland & - & - & - & 3.810 & 34.20 & 0.530 & - \\
\hline Lazarević et al. (2012) & Serbia & $13.41-22.48$ & - & - & $3.980-5.400$ & $8.20-26.20$ & $0.300-0.760$ & - \\
\hline Matović et al. (2018) & Serbia & 17.20 & & & & 12.18 & 0.390 & 0.060 \\
\hline Tomczyk et al. (2019) & Slovakia & 18.35 & - & - & 3.900 & 21.60 & 0.230 & - \\
\hline \multicolumn{9}{|c|}{ Acacia } \\
\hline Present study & Romania & $16.20-20.52$ & $78.08-82.27$ & $1.414-1.443$ & $3.673-5.503$ & $2.40-17.00$ & $0.130-0.500$ & $0.030-0.242$ \\
\hline Stihi et al. (2016) & Romania & $16.70-22.80$ & - & - & $3.650-4.630$ & - & $0.097-0.268$ & - \\
\hline $\begin{array}{l}\text { Mărghitaș et al. } \\
(2009)\end{array}$ & Romania & $16.60-19.80$ & - & - & - & - & - & $0.030-0.280$ \\
\hline $\begin{array}{l}\text { Mărghitaș et al. } \\
(2010)\end{array}$ & Romania & $17.20-19.00$ & - & - & $3.860-4.090$ & $1.84-10.87$ & $0.098-0.212$ & - \\
\hline Cimpoiu et al. (2013) & Romania & - & - & - & - & - & - & $0.040-0.270$ \\
\hline Popescu et al. (2015) & Romania & $3.90-6.20$ & $78.30-83.60$ & - & $3.700-4.300$ & - & $0.110-0.270$ & - \\
\hline Scripcă et al. (2019) & Romania & $16.30-18.00$ & & & - & - & $0.220-0.350$ & - \\
\hline Ahamed et al. (2017) & Saudi Arabia & $8.80-13.85$ & - & $1.420-1.460$ & $3.320-3.770$ & $19.80-65.00$ & $0.364-1.207$ & $0.020-0.200$ \\
\hline Attri (2011) & India & $17.07-17.20$ & - & $1.426-1.440$ & - & - & $0.240-0.380$ & $0.010-0.100$ \\
\hline Lazarević et al. (2012) & Serbia & $13.90-20.57$ & - & - & $3.490-5.850$ & $7.80-29.60$ & $0.100-0.680$ & - \\
\hline Tomczyk et al. (2019) & Poland & 17.73 & - & - & 3.790 & 25.60 & 0.420 & - \\
\hline Tomczyk et al. (2019) & Slovakia & 17.86 & - & - & 3.710 & 16.10 & 0.200 & - \\
\hline \multicolumn{9}{|c|}{ Multifloral } \\
\hline Present study & Romania & $15.83-20.77$ & $77.83-82.67$ & $1.414-1.446$ & $3.761-4.468$ & $15.60-50.00$ & $0.210-0.679$ & $0.088-0.277$ \\
\hline Pauliuc et al. 2020 & Romania & 19.60 & - & - & 4.090 & 23.90 & 0.354 & - \\
\hline Popescu et al. 2015 & Romania & $4.80-7.40$ & $80.20-83.00$ & - & $3.200-4.600$ & - & $0.232-0.831$ & - \\
\hline Cimpoiu et al. 2013 & Romania & & - & - & - & - & - & $0.050-0.100$ \\
\hline Scripcă et al. 2019 & Romania & 15.90-17.90 & - & - & - & - & $0.280-0.450$ & - \\
\hline Aazza et al. (2013) & Portugal & $19.00-19.90$ & - & - & $3.750-3.870$ & $28.62-39.75$ & $0.358-0.469$ & $0.170-0.330$ \\
\hline $\begin{array}{l}\text { Anguebes et al. } \\
\text { (2016) }\end{array}$ & Mexico & $14.15-18.94$ & $82.44-86.06$ & - & $3.800-4.400$ & 15.77-23.03 & $0.580-0.680$ & $0.120-0.160$ \\
\hline Halouzka et al. (2016) & $\begin{array}{l}\text { Czech } \\
\text { Republic }\end{array}$ & $17.00-18.20$ & - & - & $3.870-4.390$ & $15.70-17.80$ & $0.270-0.670$ & - \\
\hline Cantarelli et al. (2008) & Argentine & $14.28-18.60$ & - & - & $3.340-4.700$ & $21.23-43.20$ & - & $0.060-0.210$ \\
\hline Giorgi et al. (2011) & Italy & $16.30-17.30$ & - & - & $3.850-4.510$ & $9.00-29.00$ & $0.150-0.780$ & - \\
\hline $\begin{array}{l}\text { Kędzierska-Matysek } \\
\text { et al. (2018) }\end{array}$ & Poland & 18.40 & 80.10 & - & 4.730 & 4.50 & 0.371 & - \\
\hline Tomczyk et al. (2019) & Poland & 18.65 & - & - & 3.570 & 37.00 & 0.350 & \\
\hline Khalil et al. (2012) & Algeria & $11.59-14.13$ & - & - & $3.700-4.000$ & - & $0.417-0.806$ & - \\
\hline $\begin{array}{l}\text { Krishnasree and } \\
\text { Ukkuru (2017) }\end{array}$ & India & $13.30-14.38$ & $76.00-77.50$ & $1.380-1.400$ & $3.730-3.830$ & $31.00-32.00$ & $0.130-0.310$ & $0.140-0.160$ \\
\hline Almeida et al. (2016) & Brazil & $17.46-20.28$ & - & - & $3.650-4.170$ & $12.77-48.04$ & - & $0.075-0.472$ \\
\hline Tomczyk et al. (2019) & Slovakia & 18.53 & - & - & 3.680 & 23.30 & 0.210 & - \\
\hline $\begin{array}{l}\text { Kahraman et al. } \\
\text { (2010) }\end{array}$ & Turkey & $15.30-16.90$ & - & - & - & $23.90-24.40$ & - & $0.280-0.290$ \\
\hline
\end{tabular}

M-moisture. SS—solid substances. TSS—total soluble substances. SG—specific gravity. FA—free acidity. EC—electrical conductivity.

The first thing the consumer does with honey is the visual inspection and the color is an attractive attribute, having a strong role in the price setting, the acceptability and the degree of purchase of the product [30]. Acacia samples' pigmentation ranged from waterish white to extra white, and the linden honey color oscillated between white and light amber, while in multifloral samples, the color had darker shades from extra white to light amber. The darkest colors, light amber, were found in $20.59 \%$ out of all samples (seven 
samples of honey); eleven samples of acacia honey (29.41\% of the total studied samples) had the lightest color, water white color.

Many studies investigated the chromatic of acacia, linden and multifloral honey. Some studies reported different mm Pfund values between 11 and $219.42 \mathrm{~mm}$ Pfund [15,31-35]. Pigmentation was reported as positively correlated with certain organic compounds in honey (total phenolic and flavonoids), as well as with their induced subsequent antioxidant activity $[14,19,36-38]$. Further, dark-tinted honey seems to be richer in minerals than light honey $[1,32,39]$.

The type of nectar as well as its collection period, water, air, soil of each geographical region, processing operations and lengths and conditions of storage are responsible for the variety of colors [40,41]. In our findings, the color of raw honey samples (linden and multifloral) indicated good quality in terms of nutrition.

The refractive method is the most used method because it is easy to carry out and it can be reproduced without difficulty. Refractive index is a parameter whose value is correlated to and dependent on the values of other parameters, such as water content, solids substances, total soluble solids and specific gravity. The higher the refractive index, the lower the moisture content. Low values of moisture content prevent fermentation of honey and increase shelf life and also the storage time [42]. Less than $20 \%$ water content is recommended to be in honey, according to international regulations, transposed in Romanian standards $[10,11]$. In this study, three honey samples $(8.82 \%$ of total) with a higher moisture content than the maximum legally allowed limit of $20 \%$ were identified. However, if kept in optimal storage conditions, in a room with low humidity, at $10^{\circ} \mathrm{C}$, away from sunlight, the conservation status is improved and there is no risk of fermentative process occurrence. The highest range of water content was found in multifloral honey, from $15.83 \%$ to $20.77 \%$. Studies have shown that the moisture content had a large interval of values, from $4.8 \%$ to $22.8 \%$, in multifloral Romanian honey [32,43-45]. Moisture content ranged from $14.15 \%$ to $18.94 \%$ of honey samples from Mexico and Argentina [21,46]. The values of moisture content in acacia honey from Serbia found by [47] fell within the $13.90-20.57 \%$ interval and between the 13.41 and $22.48 \%$ limits in linden honey samples. To prevent mold growth in honey, in order to improve preservation and storage, it is compulsory to assess and monitor the moisture content [48].

Solids reversely correlated with moisture. The higher the solids level, the richer the content of sugars and minerals. Linden honey samples had the highest average solid substances, $82.58 \%$, and the poorest level of moisture, $17.42 \%$.

Most of the total soluble solids in honey are sugars. In general, the amount of total soluble solids is $80 \%$ or above [49]. According to the grading system of the United States Department of Agriculture, when results exceed $80^{\circ}$ Brix $(<20 \%$ water), honey is qualitative and has better stability during storage, as moisture decreases when the total soluble solids level increases [17]. This classification refers, in particular, to an additional insurance in terms of water content (total soluble solids are reversely correlated with water and with safety during storage for a longer period). Although, in this research, ten honey samples had a total soluble solids content between $77.83 \%$ and $80 \%$, less than the established value of $80 \%$ by the USDA, their nutritional quality is high and relatively stable during storage.

The specific gravity of honey is inversely related to its moisture; the denser a honey, the less humidity it will possess [50]. The lowest average specific gravity was measured in acacia honey $\left(1.430 \mathrm{~g} / \mathrm{cm}^{3}\right)$, while the highest one $\left(\right.$ of $\left.1.435 \mathrm{~g} / \mathrm{cm}^{3}\right)$ was measured in linden samples. Quite close values, between 1.426 and $1.440 \mathrm{~g} / \mathrm{cm}^{3}$, were found by Attri [50] in Indian honey and between 1.42 and $1.46 \mathrm{~g} / \mathrm{cm}^{3}$ by Ahamed et al. [18] in honey from Saudi Arabia. Lower values were found, $1.40 \mathrm{~g} / \mathrm{cm}$, by [49] in Indian raw honey. It is important to know the specific gravity because this parameter can reveal whether or not the honey is counterfeit and whether it has a practical significance in keeping track of the amount of honey stored $[20,23]$.

While most of the honey varieties have $\mathrm{pH}$ values between 3.5 and 5.5 , this parameter is not legislated. The $\mathrm{pH}$ values we measured fell within the above interval. Lower $\mathrm{pH}$ 
values guarantee bacteriostatic and fungi static effects, rendering this alimentary raw matter more fit to be included in processed food products, due to the higher acidity which creates asepsis [51]. Further, acidity is relevant during honey extraction and preservation because it will affect the subsequent sensorial properties via texture, overall stability and minimal durability as a marketed product $[37,49,52]$. Specifically, the investigated samples had $\mathrm{pH}$ values that oscillated between 3.673 and 5.398. Other $\mathrm{pH}$ values, from 3.65 to 4.70, have been reported for Romanian honey [43,45,53,54].

Honey is an acid food. Acidity is influenced by chemical properties of the organic and inorganic acids. Further, the action of glucose oxidase could induce alterations of honey acidity via gluconic acid accumulation [19]. Moreover, other biochemical species, such as lactones, esters and even inorganic acids, could influence the concentration of lactic acid in honey, influencing thus its free acidity level [32]. This parameter is important because its value is a measure of honey freshness. All of the free acidity values from the investigated honey samples were lower than 50 milliequivalents acid per $1000 \mathrm{~g}$, the maximum allowed value specified by the legislation (European Commission, 2002). The lowest free acidity was obtained in an acacia sample (A10 sample). Figure 5 reveals the lowest values of acacia samples, between 2.4 and $17.0 \mathrm{meq} \mathrm{kg^{-1 }}$. The highest value of 27.1 meq kg ${ }^{-1}$ was measured in multifloral honey, and then intermediate acidity was observed in linden samples $\left(24.7 \mathrm{meq} \mathrm{kg}^{-1}\right)$. In other studies, free acidity values were close to our findings: 21.6 meq kg ${ }^{-1}$ in Slovakian linden honey [55], 7.8-29.6 meq kg-1 in Serbian acacia honey [56] and 28.62-39.75 meq kg ${ }^{-1}$ in multifloral Portuguese honey [56].

Ash and its positively correlated conductivity are traits used to differentiate blossom honey from honeydew honey [2]. Ash content is given by the macro- and micro-elements of honey, which fall under the influence of the composition of collected nectar. Minerals are important nutritional compounds, with relevance in consumers' health and welfare [1]. Blossom honey is poorer as a mineral content, which ranged between 0.02 and $0.3 \%$. Variation limits of $0.03 \%$ and $0.277 \%$ were found in our original investigations. Linden honey had the richest ash content, $0.225 \%$, with individual samples ranging from $0.080 \%$ to $0.543 \%$; acacia honey had the lowest average ash content, of $0.088 \%$. Other researchers reported ash content in Romanian honey from $0.03 \%$ to $0.08 \%$ in acacia, from $0.05 \%$ to $0.10 \%$ in multifloral honey $[31,54]$ and $0.186 \%$ in the linden sort [44]. In Argentine multifloral honey, ash content was found between $0.06 \%$ and $0.21 \%$ [21], while Kahraman et al. [57] found $0.28-0.29 \%$ in Turkey honey. The amount of ash in investigated samples confirms the qualities of honey, knowing that they contain many essential mineral elements that play an important role in human metabolism.

Electrical conductivity $(\mathrm{EC})$ indicates the property of a generic material to conduct an electric current. In honey, it is straightly influenced by the nectar botanical origin, as well as by other inorganic or organic molecules that could act as electrolytes, such as ions, organic acids and proteins [40]. Directive 2001/110/EC of the European Union (amended in 2007) specifies the upper level of allowed electrical conductivity for honey of nectar, $0.8 \mu \mathrm{S} \mathrm{cm}^{-1}$, with an exception in chestnut honey which should be above $0,8 \mu \mathrm{S} \mathrm{cm}{ }^{-1}$ [11]. The found electrical conductivity ranged between 130 in acacia honey and $679 \mu \mathrm{Sm}^{-1}$ in multifloral honey. The highest average value of $506 \mu \mathrm{S} \mathrm{cm}^{-1}$ was found in linden honey.

A variability of values of this parameter was observed within the same type of honey: in acacia, values ranged from 130 to $500 \mu \mathrm{S} \mathrm{cm}^{-1}$, and in linden between 279 and $646 \mu \mathrm{S} \mathrm{cm}^{-1}$, while in multifloral honey, the values were measured between 210 and $679 \mu \mathrm{cm}^{-1}$. Pretty similar dynamics of values were reported in Romanian samples: between 202 and $730 \mu \mathrm{S} \mathrm{cm}-1$ in linden honey [5,43-45,58]; between 97 and $350 \mu \mathrm{S} \mathrm{cm}^{-1}$ in acacia $[5,43,45,49,58]$; and between 232 and $831 \mu \mathrm{S} \mathrm{cm}{ }^{-1}$ in multifloral honey [32,39,45].

Table 2 reveals the results of some parameters, from other studies, i.e., honey samples from different countries [7,47,59-62].

All values of electrical conductivity measured in our study revealed that samples originated from blossom honey and the value of this parameter, closely related to organic acids and to mineral salts, is an indicator which contributes to quality. 
A strong negative correlation between moisture and three parameters was calculated: solid substances, total soluble substances and specific gravity $(r=-1)$. A moderate negative correlation was observed between water-insoluble substances and four other parameters: refractive index $(\mathrm{r}=-0.54)$, solid substances $(\mathrm{r}=-0.54)$, total soluble substances and specific gravity $(r=-0.53)$. Mild positive correlations were calculated between moisture and water-insoluble substances $(\mathrm{r}=0.54)$; between free acidity and electrical conductivity $(\mathrm{r}=-0.53)$; and between color ( $\mathrm{mm}$ Pfund) and electrical conductivity $(\mathrm{r}=0.57)$, ash $(r=0.56)$ and free acidity $(r=0.63)$. Strong positive correlations were identified between ash and electrical conductivity $(r=0.81)$, Figure 7 ; refractive index was strongly positively correlated with three parameters: specific gravity $(\mathrm{r}=0.99)$, total soluble substances $(r=1)$, solid substances $(r=1)$; solid substances had a strong positive correlation with two parameters: total soluble substances $(r=1)$ and specific gravity $(r=1)$, while total soluble substances had a strong positive correlation with specific gravity $(\mathrm{r}=1)$.

Our original findings are comparable with the results obtained in other investigations by Attri, Gomes et al. and El Sohaimy et al. [50,51,63], which found positive strong correlations between mineral content and conductivity $(r=0.93)$ and acidity $(r=0.75)$.

Krishnasree and Ukkuru [49] observed direct correlations between the pairs $\mathrm{pH}-$ moisture, $\mathrm{pH}$-acidity and acidity-ash, and Majewska et al. [64] found a positive strong correlation between conductivity and ash, while Baloš et al. [9] found that conductivity is closely inter-related to the concentration of minerals and organic acids.

A PCA score plot was constructed for visualizing the relationship between physicochemical parameters, and positive correlations between refractive index, solid substances, total soluble substances and specific gravity could be noticed. A correlation was also observed between four parameters: color (mm Pfund), electrical conductivity, ash and free acidity.

HCA showed similarities between honey samples based on the investigated honey parameters, and in Figure 9, four clusters are observed. There are some different types of honey samples with similarities to the studied parameters, as it is observed in the first cluster that comprises nine acacia, one linden and three multifloral honey samples. The second cluster has two acacia, two linden and four multifloral honey samples. The third cluster has one acacia, four linden and two multifloral honey samples. The last clusters have three linden and three multifloral honey samples.

\section{Conclusions}

Among all analyzed samples from eastern Romania, $79.42 \%$ were in accordance with the quality regulations for honey as a commercial product.

Those honey samples exceeding the moisture upper limit of $20 \%$ do not present a risk of fermentative alteration if they are conditioned in a specially prepared drying room to gradually remove water excess and then conditioned and prepared to be marketed.

Free acidity assessments underlined the acid characteristic of honey, especially in acacia sorts. The different values for the mineral content reveal the nectar was harvested from different floral regions in eastern Romania. The floral origin was also confirmed by electrical conductivity levels below $800 \mu \mathrm{S} \mathrm{cm}-1$.

Hierarchical cluster analysis revealed that honey samples belonging to different sorts could have close values of the physico-chemical traits.

The quality of honey is highly dependent on many factors such as the year of sample collection, variety of landforms and diversity of the flora, as the data of this study revealed, basing on the diversity of raw honey quality from east Romania.

Author Contributions: Conceptualization, A.A. and I.M.P.; methodology, A.A. and C.-G.R.-R.; software, A.A. and C.-G.R.-R.; validation, A.A. and I.M.P.; formal analysis, A.A., C.-G.R.-R., G.F. and G.N.; investigation, A.A., C.-G.R.-R., G.F. and G.N.; data curation, A.A. and I.M.P.; writing-original draft preparation, A.A. and C.-G.R.-R.; writing-review and editing, A.A., C.-G.R.-R. and I.M.P.; supervision, A.A. All authors have read and agreed to the published version of the manuscript. 
Funding: This research received no external funding.

Institutional Review Board Statement: Not applicable.

Informed Consent Statement: Not applicable.

Data Availability Statement: The data presented in this study are available on request from the corresponding author.

Conflicts of Interest: The authors declare no conflict of interest.

\section{References}

1. Solayman, M.; Islam, M.A.; Paul, S.; Ali, Y.; Khalil, M.I.; Alam, N.; Gan, S.H. Physicochemical properties, minerals, trace elements, and heavy metals in honey of different origins: A comprehensive review. Compr. Rev. Food Sci. Food Saf. 2016, 15, $219-233$. [CrossRef]

2. Pita-Calvo, C.; Vázquez, M. Differences between honeydew and blossom honeys: A review. Trends Food Sci. Technol. 2017, 59, 79-87. [CrossRef]

3. Pasupuleti, V.R.; Sammugam, L.; Ramesh, N.; Gan, S.H. Honey, propolis, and royal jelly: A comprehensive review of their biological actions and health benefits. Oxidative Med. Cell. Longev. 2017, 2012, 21. [CrossRef]

4. Mădaş, N.M.; Mărghitaş, L.A.; Dezmirean, D.S.; Bonta, V.; Bobiş, O.; Fauconnier, M.L.; Francis, F.; Haubruge, E.; Nguyen, K.B. Volatile profile and physico-chemical analysis of acacia honey for geographical origin and nutritional value determination. Foods 2019, 8, 445. [CrossRef]

5. Oroian, M.; Amariei, S.; Leahu, A.; Gutt, G. Multi-Element Composition of Honey as a Suitable Tool for Its Authenticity Analysis. Pol. J. Food Nutr. Sci. 2015, 65, 93-100. [CrossRef]

6. Dobre, I.; Alexe, P.; Escuredo, O.; Seijo, C.M. Palynological evaluation of selected honeys from Romania. Grana 2013, 52, $113-121$. [CrossRef]

7. Czipa, N.; Kovács, B. Electrical conductivity of hungarian honeys. J. Food Phys. 2014, 27, 13-20.

8. Puścion-Jakubik, A.; Borawska, M.H.; Socha, K. Modern Methods for Assessing the Quality of Bee Honey and Botanical Origin Identification. Foods 2020, 9, 1028. [CrossRef] [PubMed]

9. Baloš, M.Ž.; Popov, N.; Vidaković, S.; Pelić, D.L.; Pelić, M.; Mihaljev, Ž.; Jakšić, S. Electrical conductivity and acidity of honey. Arch. Vet. Med. 2018, 11, 91-101. [CrossRef]

10. Romanian Standards Association. SR (Romanian Standard) 784-3:2009: Miere de albine. Partea 3: Metode de analiză. Honey bee. Part 3: Analytical methods. Available online: https://e-standard.eu/en/standard/174480 (accessed on 16 April 2018).

11. European Commission. Council Directive 2001/110/CE concerning honey. Off. J. Eur.Comm. 2002, L10, 47-52.

12. Bogdanov, S. 2009: Harmonized Methods of the International Honey Commission. Available online: https://www.ihc-platform. net/ihcmethods2009.pdf (accessed on 30 May 2018).

13. Czipa, N.; Phillips, C.J.; Kovács, B. Composition of acacia honeys following processing, storage and adulteration. J. Food Sci. Technol. 2019, 56, 1245-1255. [CrossRef] [PubMed]

14. Pontis, J.A.; Costa, L.A.M.A.D.; Silva, S.J.R.D.; Flach, A. Color, phenolic and flavonoid content, and antioxidant activity of honey from Roraima, Brazil. Food Sci. Technol. 2014, 34, 69-73. [CrossRef]

15. Ratiu, I.A.; Al-Suod, H.; Bukowska, M.; Ligor, M.; Buszewski, B. Correlation study of honey regarding their physicochemical properties and sugars and cyclitols content. Molecules 2020, 25, 34. [CrossRef] [PubMed]

16. Rebiai, A.; Lanez, T. Comparative study of honey collected from different flora of Algeria. J. Fundam. Appl. Sci. 2014, 6, 48-55. [CrossRef]

17. USDA. Extracted Honey Grading Manual, United States Department of Agriculture. Standards for Honey Grading; USDA: Washington, DC, USA, 1985. Available online: https://www.ams.usda.gov/sites/default/files/media/Extracted_Honey_Inspection_ Instructions\%5B1\%5D.pdf (accessed on 10 December 2018).

18. Ahamed, M.M.E.; Abdallah, A.; Abdalaziz, A.; Serag, E.; Atallah, A.B.E.H. Some physiochemical properties of Acacia honey from different altitudes of the Asir Region in Southern Saudi Arabia. Czech J. Food Sci. 2017, 35, 321-327. [CrossRef]

19. Sereia, M.J.; Março, P.H.; Perdoncini, M.R.G.; Parpinelli, R.S.; de Lima, E.G.; Anjo, F.A. Chapter 9: Techniques for the Evaluation of Physicochemical Quality and Bioactive Compounds in Honey. In Honey Analysis; INTECH: London, UK, 2017 ; pp. $194-214$.

20. Popescu, N.; Meica, S. Bee products and their chemical analysis. In Produsele Apicole și Analiza lor Chimică; Diacon Coresi: București, RO, USA, 1997.

21. Cantarelli, M.A.; Pellerano, R.G.; Marchevsky, E.J.; Camina, J.M. Quality of honey from Argentina: Study of chemical composition and trace elements. J. Argent. Chem. Soc. 2008, 96, 33-41.

22. Kivrak, ,S.; Kivrak, I.; Karababa, E. Characterization of Turkish honeys regarding of physicochemical properties, and their adulteration analysis. Food Sci. Technol. 2017, 37, 80-89. [CrossRef]

23. Crane, E. Honey: A Comprehensive Survey; Heinemann: London, UK, 1979.

24. Ahmida, N.H.; Elagori, M.; Agha, A.; Elwerfali, S.; Ahmida, M.H. Physicochemical, heavy metals and phenolic compounds analysis of Libyan honey samples collected from Benghazi during 2009-2010. Food Nutr. Sci. 2013, 4, 33-40. [CrossRef] 
25. Čelechovská, O.; Vorlová, L. Groups of honey-Physicochemical properties and heavy metals. Acta Vet. Brno 2001, 70, 91-95. [CrossRef]

26. Bakirdere, S.; Yaroglu, T.; Tirik, N.; Demiroz, M.; Karaca, A. Analysis of some physical, chemical and microbiological aspects of honey samples produced and consumed in Turkey. Rev. Fac. Cienc. Agrar. Uncuyo 2018, 50, 263-271.

27. Santos, F.K.; Dantas Filho, A.N.; Leite, R.H.; Aroucha, E.M.; Santos, A.G.; Oliveira, T.A. Rheological and some physicochemical characteristics of selected floral honeys from plants of caatinga. An. Acad. Bras. Ciências 2014, 86, 981-994. [CrossRef]

28. Directive 2014/63/EU of the European Parliament and of the Council of 15 May 2014 amending Council Directive 2001/110/EC relating to honey. Off. J. Eur. Comm. 2014, 164, 1-5.

29. Codex Alimentarius, Alinorm 01/25, Joint FAO/WHO Food Standard Programme, Codex Alimentarius Commission Twenty-fourth Session, Geneva, 2-7 July 2001. Available online: www.fao.org/download/report/277/A101_25e (accessed on 19 June 2019).

30. da Silva, P.M.; Gauche, C.; Gonzaga, L.V.; Costa, A.C.O.; Fett, R. Honey: Chemical composition, stability and authenticity. Food Chem. 2016, 196, 309-323. [CrossRef]

31. Mărghitaș, L.A.; Dezmirean, D.; Moise, A.; Bobiș, O.; Laslo, L.; Bogdanov, Ș. Physico-chemical and bioactive properties of different floral origin honeys from Romania. Food Chem. 2009, 112, 863-867. [CrossRef]

32. Pauliuc, D.; Dranca, F.; Oroian, M. Antioxidant Activity, Total Phenolic Content, Individual Phenolics and Physicochemical Parameters Suitability for Romanian Honey Authentication. Foods 2020, 9, 306. [CrossRef]

33. Almeida, A.M.M.; Oliveira, M.B.S.; Costa, J.G.; Valentim, I.B.; Goulart, M.O.F. Antioxidant Capacity, Physicochemical and Floral Characterization of Honeys from the NorthEast of Brazil. Rev. Virtual Química 2016, 8, 57-77. [CrossRef]

34. Juan-Borrás, M.; Domenech, E.; Conchado, A.; Escriche, I. Physicochemical Quality Parameters at the Reception of the Honey Packaging Process: Influence of Type of Honey, Year of Harvest, and Beekeeper. J. Chem. 2015. [CrossRef]

35. Kumazawa, S.; Okuyama, Y.; Murase, M.; Ahn, M.-R.; Nakamura, J.; Tatefuji, T. Antioxidant Activity in Honeys of Various Floral Origins: Isolation and Identification of Antioxidants in Peppermint Honey. Food Sci. Technol. Res. 2012, 18, 679-685. [CrossRef]

36. Albu, A.; Cucu-Man, S.M.; Pop, I.M. Physicochemical Parameters and Spectral Structure (Ft-Ir) of Honey From Iasi County (North-Eastern Romania). Sci. Pap. Ser. D. Anim. Sci. 2019, LXII, 206-216.

37. Khalil, M.I.; Moniruzzaman, M.; Boukraâ, L.; Benhanifia, M.; Islam, M.A.; Islam, M.N.; Sulaiman, S.A.; Gan, S.H. Physicochemical and antioxidant properties of algerian honey. Molecules 2012, 17, 11199-11215. [CrossRef]

38. Moniruzzaman, M.; Sulaiman, S.A.; Azlan, S.A.M.; Gan, S.H. Two-year variations of phenolics, flavonoids and antioxidant contents in acacia honey. Molecules 2013, 18, 14694-14710. [CrossRef]

39. White, J.W.; Doner, L.W. Honey Composition and Properties: Beekeeping in the United States. Agric. Handb. 1980, 335, 82-91.

40. de-Melo, A.A.M.; de Almeida-Muradian, L.B.; Sancho, M.T.; Pascual-Maté, A. Composition and properties of Apis mellifera honey: A reviewA. J. Apic. Res. 2017, 57, 5-37. [CrossRef]

41. Bertoncelj, J.; Doberšek, U.; Jamnik, M.; Golob, T. Evaluation of the phenolic content, antioxidant activity and colour of Slovenian honey. Food Chem. 2007, 105, 822-828. [CrossRef]

42. Soares, S.; Amaral, J.S.; Oliveira, M.B.P.; Mafra, I. A comprehensive review on the main honey authentication issues: Production and origin. Compr. Rev. Food Sci. Food Saf. 2017, 16, 1072-1100. [CrossRef]

43. Popescu, R.; Geana, E.I.; Dinca, O.R.; Sandru, C.; Costinel, D.; Ionete, R.E. Characterization of the Quality and Floral Origin of Romanian Honey. Anal. Lett. 2015, 49, 411-422. [CrossRef]

44. Purcarea, C.; Teusdea, C.A.; Chis, M.A. Chemometric Analysis of Selected Honey Samples from Western Part of Romania. Rev. De Chim. 2016, 67, 2129-2133.

45. Scripcă, L.A.; Norocel, L.; Amariei, S. Comparison of physicochemical, microbiological properties and bioactive compounds content of grassland honey and other floral origin honeys. Molecules 2019, 24, 2932. [CrossRef]

46. Anguebes, F.; Pat, L.; Ali, B.; Guerrero, A.; Córdova, A.V.; Abatal, M.; Garduza, J.P. Application of multivariable analysis and FTIR-ATR spectroscopy to the prediction of properties in campeche honey. J. Anal. Methods Chem. 2016. [CrossRef] [PubMed]

47. Lazarević, K.B.; Andrić, F.; Trifković, J.; Tešić, Ž.; Milojković-Opsenica, D. Characterisation of Serbian unifloral honeys according to their physicochemical parameters. Food Chem. 2012, 32, 2060-2064. [CrossRef]

48. Singh, I.; Singh, S. Honey moisture reduction and its quality. J. Food Sci. Technol. 2018, 55, 3861-3871. [CrossRef] [PubMed]

49. Krishnasree, V.; Ukkuru, P.M. Quality Analysis of Bee Honeys. Int. J. Curr. Microbiol. Appl. Sci 2017, 6. [CrossRef]

50. Attri, P.K. Physico-chemical investigation of honey samples of Apis cerana incica F.(Traditional Beekeeping) and Apis mellifera (Morden apiculture) from Chamba district, Himachal Pradesh. Biol Forum Int. J. 2011, 3, 67-73.

51. Gomes, S.; Dias, L.G.; Moreira, L.L.; Rodrigues, P.; Estevinho, L. Physicochemical, microbiological and antimicrobial properties of commercial honeys from Portugal. Food Chem. Toxicol. 2010, 48, 544-548. [CrossRef] [PubMed]

52. Pascual-Maté, A.; Osés, S.M.; Fernández-Muiño, M.A.; Sancho, M.T.J. Review article: Methods of analysis of honey. Apic. Res. 2018, 57, 38-74. [CrossRef]

53. Mărghitaș, L.A.; Dezmirean, D.S.; Pocol, C.B.; Marioara, I.; Bobiș, O.; Gergen, I. The development of a biochemical profile of acacia honey by identifying biochemical determinants of its quality. Not. Bot. Horti Agrobot. Cluj-Napoca 2010, 38, 84-90.

54. Cimpoiu, C.; Hosu, A.; Miclaus, V.; Puscas, A. Determination of the floral origin of some Romanian honeys on the basis of physical and biochemical properties. Spectrochim. Acta Part A 2013, 100, 149-154. [CrossRef]

55. Tomczyk, M.; Tarapatskyy, M.; Dzugan, M. The influence of geographical origin on honey composition studied by Polish and Slovak honeys. Czech J. Food Sci. 2019, 37, 232-238. [CrossRef] 
56. Aazza, S.; Lyoussi, B.; Antunes, D.; Miguel, M.G. Physicochemical Characterization and Antioxidant Activity of Commercial Portuguese Honeys. J. Food Sci. 2013, 78, 1159-1165. [CrossRef]

57. Kahraman, T.; Buyukunal, S.K.; Vural, A.; Altunatmaz, S.S. Physico-chemical properties in honey from different regions of Turkey. Food Chem. 2010, 123, 41-44. [CrossRef]

58. Stihi, C.; Chelărescu, E.D.; Duliu, O.G.; Toma, L.G. Characterization of Romanian honey using physico-chemical parameters and the elemental content determined by analytical techniques. Rom. Rep. Phys. 2016, 68, 362-369.

59. Matović, K.; Ćirić, J.; Kaljević, V.; Nedić, N.; Jevtić, G.; Vasković, N.; Baltić, M.Ž. Physicochemical parameters and microbiological status of honey produced in an urban environment in Serbia. Environ. Sci. Pollut. Res. 2018, 25, 14148-14157. [CrossRef]

60. Giorgi, A.; Madeo, M.; Baumgartner, J.; Lozzia, G.C. The Relationships between Phenolic Content, Pollen Diversity, Physicochemical Information and Radical Scavenging Activity in Honey. Molecules 2011, 16, 336-347. [CrossRef] [PubMed]

61. Kędzierska-Matysek, M.; Matwijczuk, A.; Florek, M.; Barłowska, J.; Wolanciuk, A.; Matwijczuk, A.; Chruściel, E.; Walkowiak, R.; Karcz, D.; Gładyszewska, B. Application of FTIR spectroscopy for analysis of the quality of honey. Bio. Web Conf. 2018, 10, 02008. [CrossRef]

62. Halouzka, R.; Tarkowski, P.; Zeljković, S.Ć. Characterisation of Phenolics and other Quality Parameters.of Different Types of Honey. Czech J. Food Sci. 2016, 34, 244-253.

63. El Sohaimy, S.A.; Masry, S.H.D.; Shehata, M.G. Physicochemical characteristics of honey from different origins. Ann. Agric. Sci. 2015, 60, 279-287. [CrossRef]

64. Majewska, E.; Druzynska, B.; Wołosiak, R. Determination of the botanical origin of honeybee honeys based on the analysis of their selected physicochemical parameters coupled with chemometric assays. Food Sci. Biotechnol. 2019, 28, 1307-1314. [CrossRef] [PubMed] 